University of Nebraska - Lincoln

DigitalCommons@University of Nebraska - Lincoln

The George Eliot Review

English, Department of

2009

Editors' Note- 2009 Special Issue

Follow this and additional works at: https://digitalcommons.unl.edu/ger

Part of the Comparative Literature Commons, Literature in English, British Isles Commons, and the Women's Studies Commons

"Editors' Note- 2009 Special Issue" (2009). The George Eliot Review. 697.

https://digitalcommons.unl.edu/ger/697

This Article is brought to you for free and open access by the English, Department of at DigitalCommons@University of Nebraska - Lincoln. It has been accepted for inclusion in The George Eliot Review by an authorized administrator of DigitalCommons@University of Nebraska - Lincoln. 
George Eliot Review 40 (Special Issue, 2009)

Published by the George Eliot Fellowship, https://georgeeliotreview.oeg

\section{EDITORS’ NOTE}

The Conference on 'George Eliot's Beginnings' at the Institute of English Studies on 1 November 2008 was organized by Rosemary Ashton, Beryl Gray and Barbara Hardy. The publication in volume form of Scenes of Clerical Life in 1858 was the point at which Mary Ann Evans became 'George Eliot' and we think it appropriate to mark this event by publishing the proceedings of the Conference as a Special Issue. 